\title{
Impact of dicyandiamide on emissions of nitrous oxide, nitric oxide and ammonia from agricultural field in the North China Plain
}

\author{
Yizhen Zhou ${ }^{1,2}$, Yuanyuan Zhang ${ }^{1}$, Di Tian ${ }^{1,2}$, Yujing $\mathrm{Mu}^{1, *}$ \\ 1. Research Center for Eco-Environmental Sciences, Chinese Academy of Sciences, Beijing 100085, China. E-mail: zhouyizhen0519@163.com \\ 2. University of Chinese Academy of Sciences, Beijing 100049, China
}

\section{A R T I C L E I N F O}

Article history:

Received 7 April 2015

Revised 22 August 2015

Accepted 26 August 2015

Available online 17 December 2015

Keywords:

Dicyandiamide

Nitrous oxide

Nitric oxide

Ammonia

North China Plain

\begin{abstract}
A B S T R A C T
Nitrous oxide $\left(\mathrm{N}_{2} \mathrm{O}\right)$, nitric oxide $(\mathrm{NO})$ and ammonia $\left(\mathrm{NH}_{3}\right)$ emissions from an agricultural field in the North China Plain were compared for three treatments during a whole maize growing period from 26 June to 11 October, 2012. Compared with the control treatment (without fertilization, designated as $\mathrm{CK}$ ), remarkable pulse emissions of $\mathrm{N}_{2} \mathrm{O}$, $\mathrm{NO}$ and $\mathrm{NH}_{3}$ were observed from the normal fertilization treatment (designated as NP) just after fertilization, whereas only $\mathrm{N}_{2} \mathrm{O}$ and $\mathrm{NH}_{3}$ pulse emissions were evident from the nitrification inhibitor treatment (designated as ND). The reduction proportions of $\mathrm{N}_{2} \mathrm{O}$ and $\mathrm{NO}$ emissions from the ND treatment compared to those from the NP treatment during the whole maize growing period were $31 \%$ and $100 \%$, respectively. A measurable increase of $\mathrm{NH}_{3}$ emission from the ND treatment was found with a cumulative $\mathrm{NH}_{3}$ emission of $3.8 \pm 1.2 \mathrm{~kg} \mathrm{~N} / \mathrm{ha}$, which was 1.4 times greater than that from the NP treatment $(2.7 \pm 0.7 \mathrm{~kg} \mathrm{~N} / \mathrm{ha})$.

(C) 2015 The Research Center for Eco-Environmental Sciences, Chinese Academy of Sciences.
\end{abstract}

Published by Elsevier B.V.

\section{Introduction}

Nitrous oxide $\left(\mathrm{N}_{2} \mathrm{O}\right)$ is an important greenhouse gas and also participates in the destruction of stratospheric ozone (Crutzen, 1970). The current atmospheric mixing ratio of $\mathrm{N}_{2} \mathrm{O}$ is about $310 \mathrm{nmol} / \mathrm{mol}$ with a rate of increase of $0.2 \%-0.3 \%$ per year (Vergé et al., 2007). Nitric oxide (NO) plays a critical role in tropospheric chemistry and is the key species governing formation of tropospheric ozone (Aneja et al., 1998; Gupta et al., 2003), which is known to have adverse effects on health, vegetation and materials (Benton et al., 2000). Ammonia $\left(\mathrm{NH}_{3}\right)$, being the only alkaline gas in the air, plays an important role in neutralizing atmospheric acid components to form ammonium aerosols (Brasseur et al., 1999; Yang et al., 2010). Globally, agricultural systems are important sources of atmospheric $\mathrm{N}_{2} \mathrm{O}$, $\mathrm{NO}$ and $\mathrm{NH}_{3}$ (Jones et al., 2005; Dawar et al., 2011). It has been estimated that approximately $35 \%$ of $\mathrm{N}_{2} \mathrm{O}, 41 \%$ of $\mathrm{NO}$ and $18 \%$ of $\mathrm{NH}_{3}$ originate from agricultural soils (Yienger and Levy, 1995; Kroeze et al., 1999; Bouwman et al., 2002).

$\mathrm{N}_{2} \mathrm{O}$ and $\mathrm{NO}$ are byproducts of the soil microbial nitrification process, and intermediate products of the denitrification process. Due to diffusion restrictions of $\mathrm{N}_{2} \mathrm{O}$ and $\mathrm{NO}$ produced by denitrification in soils, field measurements have revealed that $\mathrm{N}_{2} \mathrm{O}$ and $\mathrm{NO}$ emissions from upland soils are mainly ascribed to the nitrification process (Dong et al., 2001; Wrage et al., 2001; Cai et al., 2002; Shaw et al., 2006). Dicyandiamide (DCD, $\mathrm{C}_{2} \mathrm{H}_{4} \mathrm{~N}_{4}$ ) has been found to inhibit nitrification since 1918, while it was widely applied as a product in agriculture after the 1970s in the USA (Huang et al., 2002). It has been well

\footnotetext{
* Corresponding author.

E-mail address: yjmu@rcees.ac.cn (Yujing Mu).
} 
confirmed that DCD can delay the oxidation of $\mathrm{NH}_{4}^{+}$to $\mathrm{NO}_{2}^{-}$ and $\mathrm{NO}_{3}^{-}$by slowing the activities of ammonia oxidizers in the nitrification process (Kelliher et al., 2008). DCD has been shown to effectively reduce $\mathrm{N}_{2} \mathrm{O}$ emissions from pasture (Zaman et al., 2008; Cameron et al., 2014; Robinson et al., 2014), grassland (Di and Cameron, 2003; Di et al., 2010), paddy fields (Kumar et al., 2000; Li et al., 2009) and upland soil (Majumdar et al., 2002; Vallejo et al., 2005; Meijide et al., 2007). Both NO and $\mathrm{N}_{2} \mathrm{O}$ are important byproducts of nitrification; however, only few studies (Vallejo et al., 2005; Meijide et al., 2007) have investigated the reduction effect of DCD for both $\mathrm{N}_{2} \mathrm{O}$ and NO from agricultural fields. As mentioned above, DCD can inhibit oxidation of $\mathrm{NH}_{4}^{+}$, and hence the persistence of $\mathrm{NH}_{4}^{+}$in soil with DCD application may lead to increased $\mathrm{NH}_{3}$ volatilization (Banerjee et al., 2002; Mkhabela et al., 2006). However, the results measured by limited studies were inconsistent. For example, DCD addition is reported to stimulate $\mathrm{NH}_{3}$ emissions in pasture (Zaman et al., 2008) and arable soil (Soares et al., 2012), while reduction of $\mathrm{NH}_{3}$ volatilization was observed in laboratory simulations (Dendooven et al., 1998; Tao et al., 2008). Therefore, to comprehensively estimate the effect of DCD application on the regional and global atmospheric environment, further investigations on $\mathrm{N}_{2} \mathrm{O}, \mathrm{NO}$ and $\mathrm{NH}_{3}$ emissions from various soils with addition of DCD are still needed.

The North China Plain (NCP), with an area of 35 million hectares, is one of the most important agricultural regions in China (Du et al., 2009). The croplands in the NCP are being treated with increasing amounts of $\mathrm{N}$ fertilizer, which can cause increased emissions of $\mathrm{N}_{2} \mathrm{O}, \mathrm{NO}$ and $\mathrm{NH}_{3}$ (Zou et al., 2005; Zhang et al., 2011). Many studies have mainly focused on the gaseous loss of $\mathrm{N}_{2} \mathrm{O}$ from different types of $\mathrm{N}$ fertilizer (Cai et al., 2002; Ding et al., 2007; Zhang et al., 2012; Wang et al., 2013), whereas there are few reports about the effect of DCD on $\mathrm{N}_{2} \mathrm{O}$ emission from agricultural fields in this region (Ding et al., 2011; Li et al., 2013; Yan et al., 2014). To our knowledge, there is no investigation on the effects of DCD on $\mathrm{NO}$ and $\mathrm{NH}_{3}$ emissions from the soils in the NCP. The aims of this study were to quantify the effect of DCD on $\mathrm{N}_{2} \mathrm{O}, \mathrm{NO}$ and $\mathrm{NH}_{3}$ emissions from a maize field in the NCP.

\section{Materials and methods}

\subsection{Experimental site and field treatments}

The experimental site is located in Wangdu County $\left(38^{\circ} 71^{\prime} \mathrm{N}\right.$, $\left.115^{\circ} 15^{\prime} \mathrm{E}\right)$, Hebei Province, China, and belongs to a typical region of the NCP. The field soil is classified as a sandy loam soil with $\mathrm{pH}$ (in a 1:2.5 soil-to-water ratio) of 8.7 , soil organic $C$ of $7.71 \mathrm{~g} / \mathrm{kg}$ and total $\mathrm{N}$ of $0.98 \mathrm{~g} / \mathrm{kg}$. In this region during the maize season, the mean temperature is about $23.4^{\circ} \mathrm{C}$, and the mean rainfall is about $338 \mathrm{~mm}$ (accounting for about $65 \%$ of the annual rainfall), and the mean irrigation is about $800 \mathrm{~m}^{3} / \mathrm{ha}$.

The field experiment was conducted including three treatments: control ( $\mathrm{CK}$, without fertilization), compound fertilizer (NP), and DCD combined with compound fertilizer (ND). Three replicates were designed in each treatment $(6.4 \mathrm{~m} \times 3.5 \mathrm{~m})$ for investigating emissions of $\mathrm{N}_{2} \mathrm{O}, \mathrm{NO}$ and $\mathrm{NH}_{3}$. Furthermore, each treatment was separated by a $1.2 \mathrm{~m}$ wide zone to prevent nutrient transfer between treatments.
Maize was sown on 28 June 2012 and harvested on 11 October 2012. During the summer maize season, compound fertilizer (N: $\mathrm{P}_{2} \mathrm{O}_{5} \mathrm{~K}_{2} \mathrm{O}=14 \% 16 \% 15 \%$ ) was broadcast to the NP and ND treatments as basal fertilizer $(764 \mathrm{~kg} / \mathrm{ha})$ and topdressing (493 kg/ha) on 28 June and 12 August 2012, respectively. DCD (the application rate of DCD was equal to $10 \%$ of $\mathrm{N}$ fertilizer) was simultaneously applied to the ND treatment during the two fertilizations. Flooding irrigation was carried out immediately after the basal fertilizer application, while the field was not irrigated after the topdressing because of a strong rain event with rainfall of $37 \mathrm{~mm}$. All the above field management was carried out strictly according to the cultivation practices of local farmers.

\subsection{Measurements and analysis of $\mathrm{N}_{2} \mathrm{O}, \mathrm{NO}$ and $\mathrm{NH}_{3}$}

Three opaque static chambers were used for investigating $\mathrm{N}_{2} \mathrm{O}$ emission (Zhang et al., 2011). The chambers (length $\times$ width $\times$ height: $60 \mathrm{~cm} \times 60 \mathrm{~cm} \times 90 \mathrm{~cm}$ ) were placed on corresponding pedestals, which were inserted into soil at about $10-\mathrm{cm}$ depth during the whole maize growing period. The pedestal, made of stainless steel, has a grooved gutter around its upper rim for a water seal. The pedestals of the static chambers covered four maize plants. Four air samples were collected into polyethylene-coated aluminum bags (2L, Dalian Delin Gas Packing Co., Ltd., China) by a mini-pump (NMP 830 KNDC, KNF Technology Co., Ltd., Germany) at 10-min intervals after the chambers were enclosed (5, 15, 25 and $35 \mathrm{~min})$. The daily fluxes were measured between 9:00 and 11:00 am (local time). Measurements lasted for 14 days after the application of basal fertilizer, 15 days after the topdressing and twice a week during the rest of the growing season. $\mathrm{N}_{2} \mathrm{O}$ concentrations were analyzed by a gas chromatograph (GC) (Model SP3410, Beijing Analytical Instrument Factory, China) with an electron capture detector (ECD) (Zhang et al., 2012, 2013).

Twin dynamic chambers were designed to investigate $\mathrm{NO}$ and $\mathrm{NH}_{3}$ fluxes: one with the bottom covered with Teflon film was used as reference chamber, and the other one with the bottom open was used as sample chamber. The sample chamber (inner diameter of $32 \mathrm{~cm}$, and length of $80 \mathrm{~cm}$ ) was placed on a corresponding pedestal, which was inserted into the soil at about $10-\mathrm{cm}$ depth during the whole maize growing period, and covered one maize plant. Both the reference chamber and the sample chamber were simultaneously flushed by the ambient air at a rate of $15 \mathrm{~L} / \mathrm{min}$, and the concentrations of $\mathrm{NO}$ and $\mathrm{NH}_{3}$ in the chambers would achieve a steady state after flushing of about $12 \mathrm{~min}$, when the air samples (each of $3 \mathrm{~L}$ ) from the reference and sample chambers were collected simultaneously into Teflon bags. The air samples were analyzed immediately by a chemiluminescent $\mathrm{NH}_{3}$ analyzer (Model 17i, Thermo Fisher Scientific, USA) in the field laboratory. The $\mathrm{NO}$ and $\mathrm{NH}_{3}$ fluxes were derived from the difference of their concentrations at the outlets between the sample chamber and the reference chamber (Zhang et al., 2011). The daily sampling time was from 14:00 to 16:00 (local time), and measurements lasted for 14 days after the application of basal fertilization and 15 days after the topdressing. During the sampling period, soil temperature at $5-\mathrm{cm}$ depth and air temperature inside the chambers were simultaneously recorded. 


\subsection{Soil sampling and analysis}

Soil samples were collected from the topsoil of 0-5 $\mathrm{cm}$ depth by a ring sampler $\left(100 \mathrm{~cm}^{3}\right)$ for analysis of the water-filled pore space (WFPS), and the topsoil from 0 to $10 \mathrm{~cm}$ gathered by soil auger for detection of soil $\mathrm{NH}_{4}^{+}$and $\mathrm{NO}_{3}^{-}$contents. WFPS was estimated by dividing the volumetric water content by the total soil porosity. For soil $\mathrm{NH}_{4}^{+}$and $\mathrm{NO}_{3}^{-}$contents, the mixed fresh soils $(20 \mathrm{~g})$ were extracted in $100 \mathrm{~mL}$ of $1 \mathrm{~mol} / \mathrm{L}$ $\mathrm{KCl}$ solution, filtered through filter paper, and stored frozen until analyzed by a colorimetric continuous flow analyzer (SANT++, Skalar Company, The Netherlands). The soil organic $\mathrm{C}$ and total $\mathrm{N}$ concentrations were analyzed using the wet oxidation-redox titration method and micro-Kjeldahl method (Carter, 1993), respectively.

\subsection{Data analysis}

The $\mathrm{N}_{2} \mathrm{O}$ fluxes (F) (ng N/( $\left.\left.\mathrm{m}^{2} \cdot \mathrm{sec}\right)\right)$ were calculated based on the following formula:

$F=H \times \frac{\Delta C}{\Delta t} \times \frac{P}{R T} \times M_{N} \times 10^{3}$

where $H(\mathrm{~m})$ is the geometric height, $\Delta C / \Delta t$ is the slope of the linear regression of $\mathrm{N}_{2} \mathrm{O}$ concentration $(C, \mathrm{ppbV})$ versus time $(t, \mathrm{sec}), P(\mathrm{~atm})$ is the atmospheric pressure measured in the field, $R(0.082 \mathrm{~atm} \mathrm{~L} /(\mathrm{K} \cdot \mathrm{mol}))$ is the gas constant, $T(\mathrm{~K})$ is the ambient air temperature and $\mathrm{M}_{\mathrm{N}}(28 \mathrm{~g} / \mathrm{mol})$ is the atomic weight of nitrogen in $\mathrm{N}_{2} \mathrm{O}\left(\mathrm{N}_{2} \mathrm{O}-\mathrm{N}\right)$.

The $\mathrm{NO}$ and $\mathrm{NH}_{3}$ fluxes $(\mathrm{F})\left(\mathrm{ng} \mathrm{N} /\left(\mathrm{m}^{2} \cdot \mathrm{sec}\right)\right)$ were calculated based on the following formula:

$F=\frac{\left(C_{\mathrm{x}}-C_{\mathrm{c}}\right) \mathrm{Q}}{\mathrm{S}}$

where, $C_{\mathrm{x}}$ and $C_{\mathrm{c}}(\mathrm{ng} \mathrm{N} / \mathrm{L})$ are the gas concentration in the outlet of sample chamber and reference chamber, $Q(\mathrm{~L} / \mathrm{sec})$ is the airflow rate in sample chamber and reference chamber, and $S\left(\mathrm{~m}^{2}\right)$ is the area of each chamber covering soil.

Statistical analyses were performed using SPSS 13.0 software (SPSS Inc., Chicago, USA). A one-way analysis of variance (ANOVA) was used to test the differences in the CK, NP and ND treatments in the field experiment.

\section{Results and discussion}

The emission fluxes of $\mathrm{N}_{2} \mathrm{O}$, $\mathrm{NO}$ and $\mathrm{NH}_{3}$ from the three treatments during the whole maize growing season are illustrated in Fig. 1. The detailed emission characteristics of $\mathrm{N}_{2} \mathrm{O}$, NO and $\mathrm{NH}_{3}$ will be analyzed and discussed in the following sections, respectively.

\section{1. $\mathrm{N}_{2} \mathrm{O}$ emissions}

As shown in Fig. 1a, with only small pulse emissions just after the irrigation and rainfall events, $\mathrm{N}_{2} \mathrm{O}$ emissions from the CK treatment were relatively low, with a mean emission flux of $10.7 \pm 6.5 \mathrm{ng} \mathrm{N} /\left(\mathrm{m}^{2} \cdot \mathrm{sec}\right)$ (mean $\left.\pm \mathrm{SD}\right)$. In contrast to the $\mathrm{CK}$ treatment, large $\mathrm{N}_{2} \mathrm{O}$ pulse emissions were observed from both the NP and ND treatments just after basal fertilizer
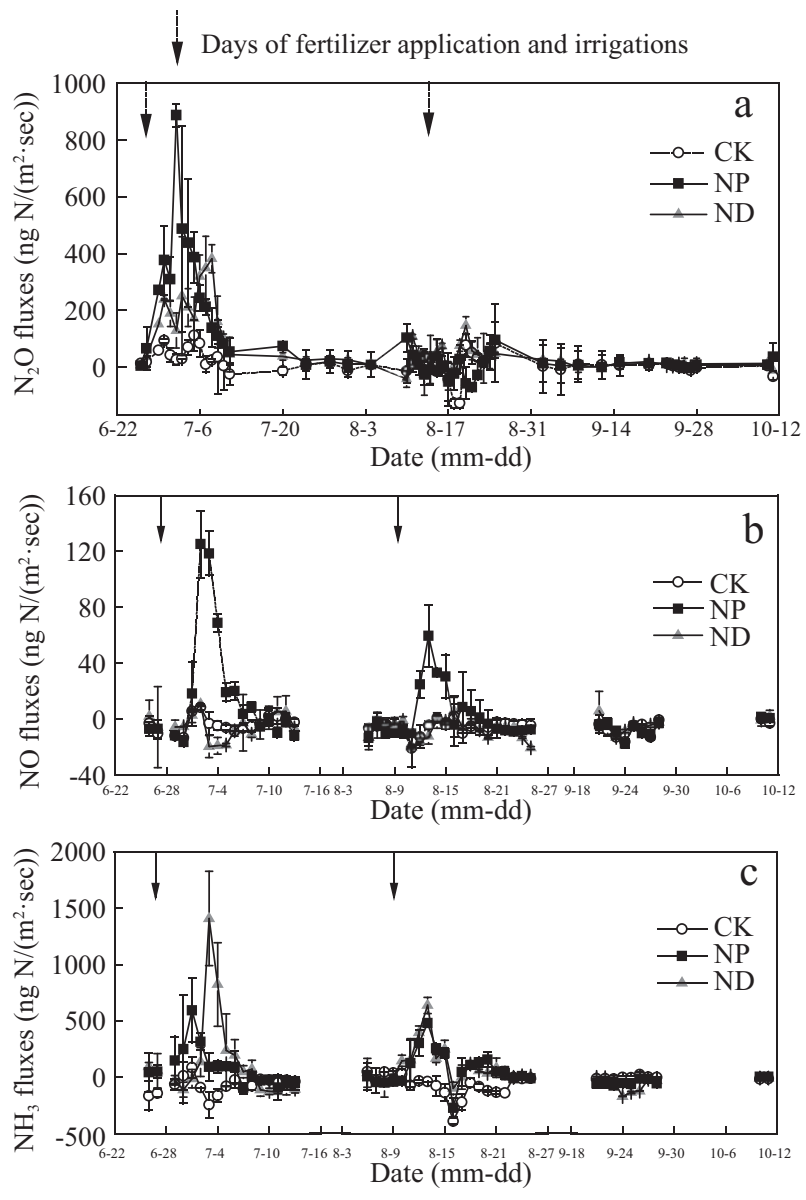

Fig. 1 - (a) $\mathrm{N}_{2} \mathrm{O}$, (b) $\mathrm{NO}$ and (c) $\mathrm{NH}_{3}$ emissions from the control (CK), the compound fertilization (NP), and dicyandiamide (DCD) combined with compound fertilizer (ND) treatments. Each value represents a mean of three replicates with standard deviation shown by vertical bars.

application. Although the two fertilization events in the NP and ND treatments significantly increased the concentrations of soil $\mathrm{NH}_{4}^{+}$and $\mathrm{NO}_{3}^{-}$(Fig. 2a, b), pulse $\mathrm{N}_{2} \mathrm{O}$ emissions from the both the treatments after topdressing on 12 August were not evident. The amount of topdressing was only about one third less than that of basal fertilization, which could not explain the large difference of $\mathrm{N}_{2} \mathrm{O}$ pulse emissions between the two fertilization events. The remarkable difference between the two fertilization events was that the basal fertilizer was applied accompanying immediate flooding irrigation and the topdressing was applied following a rainfall event $(37 \mathrm{~mm})$. The flooding irrigation after basal fertilization would quickly increase soil moisture to create a typical anoxic condition, which may favor $\mathrm{N}_{2} \mathrm{O}$ production through denitrification or nitrifier denitrification (Wrage et al., 2001). In contrast to the flooding irrigation, the rainfall after the topdressing would only gradually increase soil moisture (Fig. 2c), which may favor direct emission of the initial NO produced through nitrifier denitrification in the soil before its further reduction to $\mathrm{N}_{2} \mathrm{O}$ (as discussed in Section 2.2). In addition, the nutrient $\mathrm{N}$ may be more efficiently used by the maize crop during the topdressing than during the basal fertilization, because 
Days of fertilizer application and irrigations
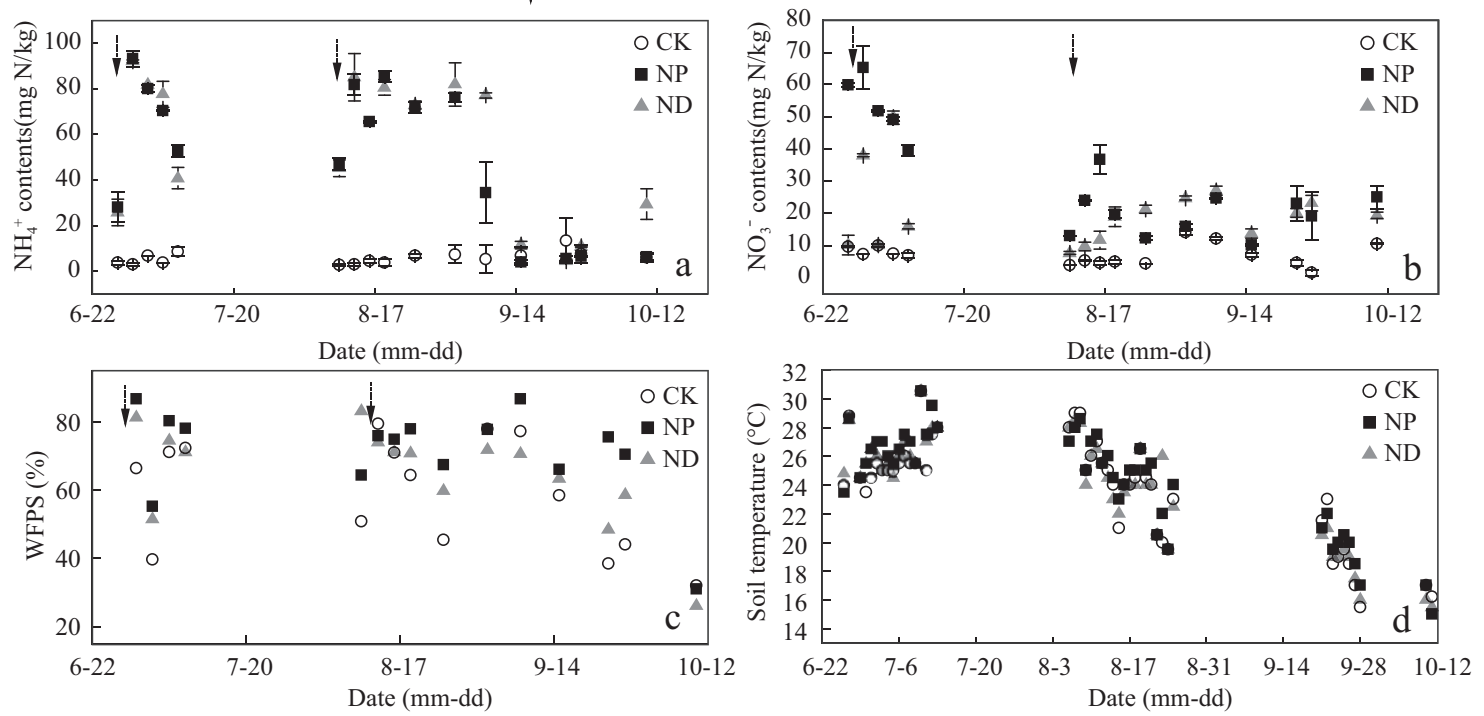

Fig. 2 - (a) Soil $\mathrm{NH}_{4}^{+}$, (b) $\mathrm{NO}_{3}^{-}$, (c) water-filled pore space (WFPS) and (d) soil temperature in the CK, NP and ND treatments.

the basal fertilizer was applied just after seeding and the topdressing was applied during the maize heading period. The competition for nutrient $\mathrm{N}$ between the crop and soil microbes would also affect $\mathrm{N}_{2} \mathrm{O}$ emission (Gao et al., 2014). Flooding irrigation may also accelerate the nitrification process, e.g., the concentrations of soil $\mathrm{NO}_{3}^{-}$after the basal fertilization were much higher than those after the topdressing (Fig. 2b), and thus favored $\mathrm{N}_{2} \mathrm{O}$ emission.

In our study, we observed $\mathrm{N}_{2} \mathrm{O}$ uptake one day after topdressing, with the maximal negative flux of $-129 \mathrm{ng} \mathrm{N} /\left(\mathrm{m}^{2} \cdot \mathrm{sec}\right)$ on 18 August. Evidently negative $\mathrm{N}_{2} \mathrm{O}$ fluxes from agricultural fields were also observed in several investigations (Mahmood et al., 1998; Ju et al., 2011; Cui et al., 2012; Yan et al., 2013; Zhang et al., 2014). Although the mechanisms and factors controlling $\mathrm{N}_{2} \mathrm{O}$ uptake are not yet well understood (Ju et al., 2011), the occasional uptake of $\mathrm{N}_{2} \mathrm{O}$ by soils was suspected to be due to the reduction of $\mathrm{N}_{2} \mathrm{O}$ under extremely anoxic conditions (Chapuis-Lardy et al., 2007). With the only exception being the topdressing fertilization in this study, remarkable pulse $\mathrm{N}_{2} \mathrm{O}$ emission from the agricultural field was observed after each fertilization event during several years' investigations (Zhang et al., 2014). The evident difference of environmental factors between the topdressing fertilization and other fertilization events is that a successive heavy rainfall $(37 \mathrm{~mm})$ just following the fertilization and irrigation occurred before 18 August, 2012. The heavy rainfall continually kept the soil under extremely high moisture, which may favor $\mathrm{N}_{2} \mathrm{O}$ reduction and result in the observed $\mathrm{N}_{2} \mathrm{O}$ uptake.

In comparison with the NP treatment, the remarkable reduction of $\mathrm{N}_{2} \mathrm{O}$ pulse emissions in the ND treatment after the basal fertilization was coincident with the lower $\mathrm{NO}_{3}^{-}$ concentrations and delayed $\mathrm{NO}_{3}^{-}$peak in the ND treatment (Fig. $2 \mathrm{a}$ and $\mathrm{b}$ ), implying that the DCD added indeed suppressed the nitrification process for oxidation of $\mathrm{NH}_{4}^{+}$ to $\mathrm{NO}_{3}^{-}$and reduced $\mathrm{N}_{2} \mathrm{O}$ emission. The $\mathrm{N}_{2} \mathrm{O}$ peak emission from the NP treatment was about a factor of 4 greater than that from the ND treatment around the fourth day after fertilization, indicating that nitrification during the fertilization period was the dominant process for $\mathrm{N}_{2} \mathrm{O}$ emission from the agricultural field. More evidence on nitrification as the dominant process for $\mathrm{N}_{2} \mathrm{O}$ emissions from several agricultural fields in the NCP has also been reported (Ju et al., 2011; Cui et al., 2012; Zhang et al., 2012). It is interesting to note that the observed reduction of $\mathrm{N}_{2} \mathrm{O}$ emission on addition of DCD only lasted for the initial 5 days after the basal fertilization, whereas there was almost no difference in the second small pulse $\mathrm{N}_{2} \mathrm{O}$ emissions between the two treatments around 10 days after the fertilization. This interesting phenomenon could probably be ascribed to the short lifetime of DCD in the soil, e.g., Bian et al. (1999) estimated the DCD half-life to be about one week at $20^{\circ} \mathrm{C}$ and shorter under higher soil temperature (Fig. 2d).

The cumulative $\mathrm{N}_{2} \mathrm{O}$ emission from the ND treatment $(4.0 \pm 0.2 \mathrm{~kg} \mathrm{~N} / \mathrm{ha})$ was $31 \%$ less than that from the NP treatment $(5.8 \pm 0.7 \mathrm{~kg} \mathrm{~N} / \mathrm{ha})$ during the whole maize season. The reduction percentage of $\mathrm{N}_{2} \mathrm{O}$ emission from the ND treatment was in the range of the values (35\%-59\%) reported by previous investigators (Dobbie and Smith, 2003; Li et al., 2013; Liu et al., 2013; Xu et al., 2000; Zaman et al., 2008). It is worth mentioning that DCD addition was able to reduce $\mathrm{N}_{2} \mathrm{O}$ emissions without affecting maize yield $(6.7 \pm 0.16,8.9 \pm 0.37$ and $8.3 \pm 0.48 \mathrm{t} / \mathrm{ha}$ for the $\mathrm{CK}, \mathrm{NP}$ and ND treatments, respectively). After subtracting $\mathrm{N}_{2} \mathrm{O}$ emission from the $\mathrm{CK}$ treatment $(1.0 \pm 0.6 \mathrm{~kg} \mathrm{~N} / \mathrm{ha})$, the $\mathrm{N}_{2} \mathrm{O}$ emission factor (EF) from the NP treatment was calculated to be $2.7 \%$, which is about two times greater than the reported values from other agricultural fields in the NCP (Cai et al., 2013; Liu et al., 2014), but still within the uncertainty range recommended by the IPCC (0.3\%-3\%; De Klein et al., 2006). Our previous study (Zhang et al., 2014) indicated that the EF values exhibited large inter-annual variation in the investigated agricultural field, ranging from $0.6 \%$ to $2.9 \%$. The sampling frequency of $\mathrm{N}_{2} \mathrm{O}$ flux measurements for most investigations in the NCP was 
usually once or twice a week, which might miss the $\mathrm{N}_{2} \mathrm{O}$ emission peaks just after fertilization events and result in relatively small EF values. The precision of $\mathrm{N}_{2} \mathrm{O}$ analysis by GC-ECD was also suspected to be partially responsible for the large variation of the EF values reported in the agricultural fields of the NCP; however, most studies did not mention the precision of their GC-ECD for detecting $\mathrm{N}_{2} \mathrm{O}$. Zheng et al. (2008) pointed out that $\mathrm{N}_{2} \mathrm{O}$ detection by GC-ECD using $\mathrm{N}_{2}$ as carrier gas can be seriously affected by $\mathrm{CO}_{2}$ in the air sample and hence influence $\mathrm{N}_{2} \mathrm{O}$ flux measurements, whereas the method has been used by most studies for investigating $\mathrm{N}_{2} \mathrm{O}$ fluxes from agricultural fields in the NCP. In addition, the different environmental factors and soil characters for different studies may also contribute to the variation of EF values from different agricultural fields in the NCP.

\subsection{NO emissions}

As shown in Fig. 1b, NO fluxes from both the CK and the ND treatments were always around zero except for the small pulse NO emissions just after the irrigation or rainfall. In contrast to the CK and ND treatments, remarkable NO pulse emissions from the NP treatment appeared after both the basal fertilization and topdressing. Although both nitrification and denitrification in soils can produce NO, NO emissions from soils are mainly ascribed to nitrification because almost all studies found that NO produced by denitrification could not escape from soils (Remde and Conrad, 1991; Skiba et al., 1993; Russow et al., 2008; Zhang et al., 2011; Cui et al., 2012). Compared with the NP treatment, the remarkable reduction of NO emission from the ND treatment indicated that the DCD applied efficiently inhibited nitrification in the agricultural soil. The observed lower $\mathrm{NO}_{3}^{-}$concentrations in the ND treatment compared to the NP treatment just a few days after fertilization (Fig. 2b) were also consistent with DCD inhibition of $\mathrm{NH}_{4}^{+}$oxidation via slowing the activity of nitrosomonas (Sanz-Cobena et al., 2012).

In comparison with the $\mathrm{CK}$ treatment, measurable NO emission from the NP treatment appeared about 3 days after basal fertilization, whereas $\mathrm{N}_{2} \mathrm{O}$ emission increased immediately. Because the flooding irrigation just following the basal fertilization could easily result in soil saturation with water in the first days, NO formed as the initial byproduct of nitrification would be further used as the electron acceptor in the nitrifier denitrification and be reduced to $\mathrm{N}_{2} \mathrm{O}$ or $\mathrm{N}_{2}$ under the extremely anoxic conditions during the first days of irrigation. In the topdressing, the soil moisture could not achieve the status of water saturation due to the gradual and limited rainfall, and NO emission from the NP treatment quickly increased just after fertilization. NO produced by nitrification under such soil moisture might easily escape from the soil into the atmosphere before its further reduction to $\mathrm{N}_{2} \mathrm{O}$ or $\mathrm{N}_{2}$, and hence very small $\mathrm{N}_{2} \mathrm{O}$ emission was observed from the NP treatment after the topdressing.

During the whole maize growing season, the average NO fluxes were $-5.2 \pm 0.7,7.4 \pm 1.9$ and $-5.3 \pm 0.03 \mathrm{ng} \mathrm{N} /\left(\mathrm{m}^{2} \cdot \mathrm{sec}\right)$ (mean $\pm \mathrm{SD}, n=47$ ) from the $\mathrm{CK}, \mathrm{NP}$ and ND treatments, respectively. Compared with the NO flux from the NP treatment, the almost identical negative NO fluxes from the CK and ND treatments indicated that the application of DCD could reduce NO loss from the fertilizer application nearly $100 \%$, which was much greater than the percentages $(37 \%-$ $78 \%$ ) reported in the literature (Meijide et al., 2007; Vallejo et al., 2005; Akiyama et al., 2015). The reduction effect of DCD on NO emission may depend on the application rate of DCD, soil character (texture, $\mathrm{pH}$, moisture and temperature), the available $\mathrm{NH}_{4}^{+}$concentration, and so on. Under the same application rate of DCD (10\%) as ours, Akiyama et al. (2015) reported that DCD could reduce $75 \%$ of NO emissions in an acid Andosol soil (a volcanic ash soil), whereas Vallejo et al. (2005) found that the NO emission was only reduced by $37 \%$ with a lower application rate of DCD (5\%) into a loam texture soil ( $\mathrm{pH}=8.1$ ). Because $\mathrm{NO}$ emission from field soil is mainly ascribed to nitrification (Zhang et al., 2011; Cui et al., 2012) and negatively correlates to soil moisture (as evidenced by the later NO emission peak from the NP treatment in comparison with $\mathrm{N}_{2} \mathrm{O}$ emission), both the suppression of nitrification by DCD application and the extremely high soil moisture after the fertilization and irrigation in this study favored reduction of NO emission, resulting in the ND treatment having the largest reduction loss rate of NO emission.

\section{3. $\mathrm{NH}_{3}$ emissions}

As shown in Fig. 1c, almost all $\mathrm{NH}_{3}$ fluxes from the $\mathrm{CK}$ treatment were below zero, implying the CK treatment acted as a sink of atmospheric $\mathrm{NH}_{3}$ over the experimental period. Because $\mathrm{NH}_{3}$ emission from soil is mainly governed by the equilibrium relationship between gaseous phase $\mathrm{NH}_{3}(\mathrm{~g})$ and aqueous phase $\mathrm{NH}_{3}$ (aq) in solution (Bolan et al., 2004), the observed pulse $\mathrm{NH}_{3}$ emissions from the NP and ND treatments after the basal fertilization and topdressing were reasonably ascribed to the abrupt increase of aqueous $\mathrm{NH}_{3}$ concentration in the soil due to the fertilization. During the basal fertilization, the $\mathrm{NH}_{3}$ emission from the NP treatment achieved a peak value of $595.9 \mathrm{ng} \mathrm{N} /\left(\mathrm{m}^{2} \cdot \mathrm{sec}\right.$ ) on 1 July (3 days after fertilization), while the $\mathrm{NH}_{3}$ emission peak from the ND treatment was $1411 \mathrm{ng} \mathrm{N} /\left(\mathrm{m}^{2} \cdot \mathrm{sec}\right)$ after 5 days of fertilization. During the period of topdressing, the $\mathrm{NH}_{3}$ emission peaks from the NP and ND treatments occurred on the same day (2 days after topdressing) with the value of 480.8 and $638.9 \mathrm{ng} \mathrm{N} /\left(\mathrm{m}^{2} \cdot \mathrm{sec}\right)$, respectively. Although the concentrations of soil $\mathrm{NH}_{4}^{+}$measured in the two treatments had no apparent difference (Fig. 2a), the stronger $\mathrm{NH}_{3}$ emission peaks from the ND treatment than from the NP treatment might be ascribed to the persistence of $\mathrm{NH}_{4}^{+}$in soil due to DCD application in the ND treatment. However, it is very difficult for us to explain the delayed $\mathrm{NH}_{3}$ emission peak during basal fertilization.

Considering only the 10 days after each fertilization, the cumulative $\mathrm{NH}_{3}$ emissions were $2.7 \pm 0.7$ and $3.8 \pm 1.2$ (mean $\pm \mathrm{SD}$ ) $\mathrm{kg}$ N/ha from the NP and ND treatments, respectively. Compared with the NP treatment, the application of DCD increased $\mathrm{NH}_{3}$ emission by $29 \%$, which was in agreement with the values $(5 \%-41 \%)$ reported by previous studies from arable land (Zaman and Blennerhassett, 2010; Soares et al., 2012). Furthermore, the cumulative $\mathrm{NH}_{3}$ emissions from the agricultural field measured by this study were much lower than those reported by previous investigators (Cai et al., 2002; Wang et al., 2004; Zaman et al., 2008; Singh et al., 2013). For 
example, Cai et al. (2002) reported that the amount of $\mathrm{NH}_{3}$ emitted was $13 \mathrm{~kg} \mathrm{~N} / \mathrm{ha}$ and Wang et al. (2004) reported $17.9 \mathrm{~kg} \mathrm{~N} / \mathrm{ha}$. All the higher $\mathrm{NH}_{3}$ emissions from agricultural fields reported were based on urea application, whereas compound fertilizer ( $\mathrm{N}$ in the form of $\mathrm{NH}_{4}^{+}$) was applied in this study. The hydrolysis of urea releases alkali ions $\left(\mathrm{OH}^{-}\right)$, thereby increasing soil $\mathrm{pH}$ to favor $\mathrm{NH}_{3}$ emission (Singh et al., 2013), whereas the $\mathrm{NH}_{4}^{+}$ion is dissociated into $\mathrm{NH}_{3}$ with release of an $\mathrm{H}^{+}$(proton), resulting in acidity in the soil.

\section{Conclusions}

Fertilization markedly induced $\mathrm{N}_{2} \mathrm{O}$, $\mathrm{NO}$ and $\mathrm{NH}_{3}$ emissions from the agricultural soil in the NCP during the maize growing season. The remarkable reduction of $\mathrm{NO}$ and $\mathrm{N}_{2} \mathrm{O}$ emissions by application of a nitrification inhibitor (DCD) confirmed that their emissions from the agricultural field were mainly from the soil microbial nitrification process. The negative effect of the evident increase of $\mathrm{NH}_{3}$ emission by the DCD on region air quality should be also considered before application of DCD in the vast agricultural fields in the NCP.

\section{Acknowledgments}

This work was financially supported by the National Key Technology R\&D Program of China (No. 2013BAD11B03-3), the Strategic Priority Research Program of the Chinese Academy of Sciences (No. XDB05010100), and the National Natural Science Foundation of China (Nos. 21477142 and 21177140).

\section{R E F E R E N C E S}

Akiyama, H., Uchida, Y., Tago, K., Hoshino, Y.T., Shimomura, Y., Wang, Y., et al., 2015. Effect of dicyandiamide and polymer coated urea applications on $\mathrm{N}_{2} \mathrm{O}$, $\mathrm{NO}$ and $\mathrm{CH} 4$ fluxes from andosol and fluvisol fields. Soil Sci. Plant Nutr. 61 (3), 541-551.

Aneja, V.P., Roelle, P.A., Robarge, W.P., 1998. Characterization of biogenic nitric oxide source strength in the southeast United States. Environ. Pollut. 102 (1 Suppl. 1), 211-218.

Banerjee, B., Pathak, H., Aggarwal, P.K., 2002. Effects of dicyandiamide, farmyard manure and irrigation on crop yields and ammonia volatilization from an alluvial soil under a rice (Oryza sativa L.)-wheat (Triticum aestivum L.) cropping system. Biol. Fertil. Soils 36 (3), 207-214.

Benton, J., Fuhrer, J., Gimeno, B.S., Skärby, L., Palmer-Brown, D., Ball, G., et al., 2000. An international cooperative programme indicates the widespread occurrence of ozone injury on crops. Agric. Ecosyst. Environ. 78 (1), 19-30.

Bian, X.J., Ju, X.T., Liu, X.J., Zhang, F.S., Li, X.L., 1999. The studies on transformation characteristics of urea applied to meadow cinnamon soil and the influencing factors. J. Agric. Univ. Hebei. 22 (4), 23-26.

Bolan, N.S., Saggar, S., Luo, J.F., Bhandral, R., Singh, J., 2004. Gaseous emissions of nitrogen from grazed pastures: processes, measurements and modelling, environmental implications, and mitigation. Adv. Agron. 84, 37-120.

Bouwman, A.F., Boumans, L.J.M., Batjes, N.H., 2002. Estimation of global $\mathrm{NH}_{3}$ volatilization loss from synthetic fertilizers and animal manure applied to arable lands and grasslands. Glob. Biogeochem. Cycles 16 (2) (8-1-8-14).

Brasseur, G.P., Orlando, J.J., Tyndall, G.S., 1999. Atmospheric Chemistry and Global Chang. Oxford University Press, New York, USA, p. 654.

Cai, G., Chen, D., White, R.E., Fan, X.H., Pacholski, A., Zhu, Z.L., et al., 2002. Gaseous nitrogen losses from urea applied to maize on a calcareous fluvo-aquic soil in the North China Plain. Aust. J. Soil Res. 40 (5), 737-748.

Cai, Y.J., Ding, W.X., Luo, J.F., 2013. Nitrous oxide emissions from Chinese maize-wheat rotation systems: a 3-year field measurement. Atmos. Environ. 65, 112-122.

Cameron, K.C., Di, H.J., Moir, J.L., 2014. Dicyandiamide (DCD) effect on nitrous oxide emissions, nitrate leaching and pasture yield in Canterbury, New Zealand. N. Z. J. Agric. Res. 57 (4), 251-270.

Carter, M.R., 1993. Soil Sampling and Methods of Analysis. Lewis Publishers, Boca Raton.

Chapuis-Lardy, L., Wrage, N., Metay, A., Chotte, J.L., Bernoux, M., 2007. Soils, a sink for $\mathrm{N}_{2} \mathrm{O}$, a review. Glob. Chang. Biol. 13, 1-17.

Crutzen, P.J., 1970. Influence of nitrogen oxides on atmospheric ozone content. Q. J. R. Meteorol. Soc. 96 (408), 320-325.

Cui, F., Yan, G.X., Zhou, Z.X., Zheng, X.H., Deng, J., 2012. Annual emissions of nitrous oxide and nitric oxide from a wheat-maize cropping system on a silt loam calcareous soil in the North China Plain. Soil Biol. Biochem. 48, 10-19.

Dawar, K., Zaman, M., Rowarth, J.S., Blennerhassett, J., Turnbull, M.H., 2011. Urease inhibitor reduces $\mathrm{N}$ losses and improves plant-bioavailability of urea applied in fine particle and granular forms under field conditions. Agric. Ecosyst. Environ. 144 (1), 41-50.

De Klein, C., Novoa, R.S.A., Ogle, S., Simith, K.A., Rochette, P., Wirth, T.C., et al., 2006. N2O emissions from managed soil, and CO2 emissions from lime and urea application, in: 2006 IPCC guidelines for national greenhouse gas inventories, Vol4-agriculture, forestry and other land use. In: Eggleston, S., Buendia, L., Miwa, K., Ngara, T., Tanabe, K. (Eds.), Institute for Global Environmental Strategies. 11 (1-11.54, Japan).

Dendooven, L., Bonhomme, E., Merckx, R., Vlassak, K., 1998. N dynamics and sources of $\mathrm{N}_{2} \mathrm{O}$ production following pig slurry application to a loamy soil. Biol. Fertil. Soils 26 (3), 224-228.

Di, H.J., Cameron, K.C., 2003. Mitigation of nitrous oxide emissions in spray irrigated grazed grassland by treating the soil with dicyandiamide, a nitrification inhibitor. Soil Use Manag. 19, 284-290.

Di, H.J., Cameron, K.C., Sherlock, R.R., Shen, J.P., He, J.Z., Wine field, C.S., 2010. Nitrous oxide emissions from grazed grassland as affected by a nitrification inhibitor, dicyandiamide, and relationships with ammonia-oxidizing bacteria and archaea. J. Soils Sediments 10, 943-954.

Ding, W., Cai, Y., Cai, Z., Yagi, K., Zheng, X., 2007. Nitrous oxide emissions from an intensively cultivated maize-wheat rotation soil in the North China Plain. Sci. Total Environ. 373, 501-511.

Ding, W.X., Yu, H.Y., Cai, Z.C., 2011. Impact of urease and nitrification inhibitors on nitrous oxide emissions from fluvo-aquic soil in the North China Plain. Biol. Fertil. Soils 47, 91-99.

Dobbie, K.E., Smith, K.A., 2003. Impact of different forms of $\mathrm{N}$ fertilizer on $\mathrm{N}_{2} \mathrm{O}$ emissions from intensive grassland. Nutr. Cycl. Agroecosyst. 67 (1), 37-46.

Dong, Y., Scharffe, D., Qi, Y.C., Peng, G.B., 2001. Nitrous oxide emissions from cultivated soils in the North China Plain. Tellus B 53 (1), 1-9.

Du, Z.L., Liu, S.F., Li, K.J., Ren, T.S., 2009. Soil organic carbon and physical quality as influenced by long-term application of residue and mineral fertiliser in the North China Plain. Aust. J. Soil Res. 47 (6), 585-591.

Gao, B., Ju, X.T., Su, F., Meng, Q.F., Oenema, O., Christie, P., et al., 2014. Nitrous oxide and methane emissions from optimized 
and alternative cereal cropping systems on the North China Plain: a two-year field study. Sci. Total Environ. 472, 112-124.

Gupta, A., Kumar, R., Kumari, K.M., Srivastava, S.S., 2003. Measurement of $\mathrm{NO}_{2}, \mathrm{HNO}_{3}, \mathrm{NH}_{3}$ and $\mathrm{SO}_{2}$ and related particulate matter at a rural site in Rampur. India. Atmos. Environ. 37 (34), 4837-4846.

Huang, Y.Z., Feng, Z.W., Wang, X.K., Zhang, F.Z., 2002. Research progress of nitrification inhibitors applied in agriculture. Chin. J. Soil Sci. 33 (4), 310-315 (in Chinese).

Jones, D.L., Healey, J.R., Willett, V.B., Farrar, J.F., Hodge, A., 2005. Dissolved organic nitrogen uptake by plants - an important $\mathrm{N}$ uptake pathway? Soil Biol. Biochem. 37 (3), 413-423.

Ju, X.T., Lu, X., Gao, Z.L., Chen, X.P., Su, F., Kogge, M., et al., 2011. Processes and factors controlling $\mathrm{N}_{2} \mathrm{O}$ production in an intensively managed low carbon calcareous soil under sub-humid monsoon conditions. Environ. Pollut. 159 (4), 1007-1016.

Kelliher, F.M., Clough, T.J., Clark, H., Rys, G., Sedcole, J.R., 2008. The temperature dependence of dicyandiamide (DCD) degradation in soils: a data synthesis. Soil Biol. Biochem. 40, 1878-1882.

Kroeze, C., Mosier, A., Bouwman, L., 1999. Closing the global $\mathrm{N}_{2} \mathrm{O}$ budget: a retrospective analysis 1500-1994. Glob. Biogeochem. Cycles 13 (1), 1-8.

Kumar, U., Jain, M.C., Pathak, H., Kumar, S., Majumdar, D., 2000. Nitrous oxide emission from different fertilizers and its mitigation by nitrification inhibitors in irrigated rice. Biol. Fertil. Soils 32, 474-478.

Li, X.L., Zhang, X.Y., Xu, H., Cai, Z.C., Yagi, K., 2009. Methane and nitrous oxide emissions from rice paddy soil as influenced by timing of application of hydroquinone and dicyandiamide. Nutr. Cycl. Agroecosyst. 85 (1), 31-40.

Li, C., Wan, Y.F., Li, Y.E., Qin, X.B., 2013. Effect of dicyandiamide and sulfur coated urea on saving cost and $\mathrm{N}_{2} \mathrm{O}$ emission reduction in spring corn field. Chin. J. Agrometeor. 34 (5), 526-531.

Liu, C., Wang, K., Zheng, X., 2013. Effects of nitrification inhibitors (DCD and DMPP) on nitrous oxide emission, crop yield and nitrogen uptake in a wheat-maize cropping system. Biogeosciences 10 (4), 2427-2437.

Liu, C.Y., Yao, Z.S., Wang, K., Zheng, X.H., 2014. Three-year measurements of nitrous oxide emissions from cotton and wheat-maize rotational cropping systems. Atmos. Environ. 96, 201-208.

Mahmood, T., Ali, R., Malik, K.A., Shamsi, S.R.A., 1998. Nitrous oxide emissions from an irrigated sandy-clay loam cropped to maize and wheat. Biol. Fertil. Soils 27 (2), 189-196.

Majumdar, D., Pathak, H., Kumar, S., Jain, M.C., 2002. Nitrous oxide emission from a sandy loam inceptisol under irrigated wheat in India as influenced by different nitrification inhibitors. Agric. Ecosyst. Environ. 91, 283-293.

Meijide, A., Díez, J.A., Sánchez-Martín, L., López-Fernández, S., Vallejo, A., 2007. Nitrogen oxide emissions from an irrigated maize crop amended with treated pig slurries and composts in a Mediterranean climate. Agric. Ecosyst. Environ. 121 (4), 383-394.

Mkhabela, M.S., Gordon, R., Burton, D., Madani, A., Hart, W., Elmi, A., 2006. Ammonia and nitrous oxide emissions from two acidic soils of Nova Scotia fertilised with liquid hog manure mixed with or without dicyandiamide. Chemosphere 65 (8), 1381-1387.

Remde, A., Conrad, R., 1991. Production and consumption of nitric-oxide by denitrifying bacteria under anaerobic and aerobic conditions. FEMS Microbiol. Lett. 80, 329-332.

Robinson, A., Di, H.J., Cameron, K.C., Podolyan, A., He, J.Z., 2014. The effect of soil pH and dicyandiamide (DCD) on $\mathrm{N}_{2} \mathrm{O}$ emissions and ammonia oxidiser abundance in a stimulated grazed pasture soil. J. Soils Sediments 14 (8), 1434-1444.

Russow, R., Spott, O., Stange, C.F., 2008. Evaluation of nitrate and ammonium as sources of $\mathrm{NO}$ and $\mathrm{N}_{2} \mathrm{O}$ emissions from black earth soils (Haplic Chernozem) based on (15)N field experiments. Soil Biol. Biochem. 40 (2), 380-391.

Sanz-Cobena, A., Sánchez-Martín, L., García-Torres, L., Vallejo, A., 2012. Gaseous emissions of $\mathrm{N}_{2} \mathrm{O}$ and $\mathrm{NO}$ and $\mathrm{NO}_{3}^{-}$leaching from urea applied with urease and nitrification inhibitors to a maize (Zea mays) crop. Agric. Ecosyst. Environ. 149, 64-73.

Shaw, L.J., Nicol, G.W., Smith, Z., Fear, J., Prosser, J.I., Baggs, E.M., 2006. Nitrosospira spp. can produce nitrous oxide via a nitrifier denitrification pathway. Environ. Microbiol. 8 (2), 214-222.

Singh, J., Kunhikrishnan, A., Bolan, N.S., Saggar, S., 2013. Impact of urease inhibitor on ammonia and nitrous oxide emissions from temperate pasture soil cores receiving urea fertilizer and cattle urine. Sci. Total Environ. 465, 56-63.

Skiba, U., Smith, K.A., Fowler, D., 1993. Nitrification and denitrification as sources of nitric-oxide and nitrous-oxide in a sandy loam soil. Soil Biol. Biochem. 25 (11), 1527-1536.

Soares, J.R., Cantarella, H., de Campos Menegale, M.L., 2012. Ammonia volatilization losses from surface-applied urea with urease and nitrification inhibitors. Soil Biol. Biochem. 52, $82-89$.

Tao, X., Matsunaka, T., Sawamoto, T., 2008. Dicyandiamide application plus incorporation into soil reduces $\mathrm{N}_{2} \mathrm{O}$ and $\mathrm{NH}_{3}$ emissions from anaerobically digested cattle slurry. Aust. J. Exp. Agric. 48 (2), 169-174.

Vallejo, A., García-Torres, L., Díez, J.A., Arce, A., López-Fernández, S., 2005. Comparison of $\mathrm{N}$ losses $\left(\mathrm{NO}_{3}^{-}, \mathrm{N}_{2} \mathrm{O}, \mathrm{NO}\right)$ from surface applied, injected or amended (DCD) pig slurry of an irrigated soil in a Mediterranean climate. Plant Soil 272 (1), 313-325.

Vergé, X.P.C., De Kimpe, C., Desjardins, R.L., 2007. Agricultural production, greenhouse gas emissions and mitigation potential. Agric. For. Meteorol. 142 (2-4), 255-269.

Wang, Z.H., Liu, X.J., Ju, X.T., Zhang, F.S., Malhi, S.S., 2004. Ammonia volatilization loss from surface-broadcast urea: comparison of vented- and closed-chamber methods and loss in winter wheat-summer maize rotation in north China plain. Commun. Soil Sci. Plant Anal. 35 (19-20), 2917-2939.

Wang, Y.Y., Hu, C.S., Ming, H., Zhang, Y.M., Li, X.X., Dong, W.X., et al., 2013. Concentration profiles of $\mathrm{CH}_{4}, \mathrm{CO}_{2}$ and $\mathrm{N}_{2} \mathrm{O}$ in soils of a wheat-maize rotation ecosystem in North China Plain, measured weekly over a whole year. Agric. Ecosyst. Environ. 164, 260-272.

Wrage, N., Velthof, G.L., van Beusichem, M.L., Oenema, O., 2001. Role of nitrifier denitrification in the production of nitrous oxide. Soil Biol. Biochem. 33 (12-13), 1723-1732.

Xu, X.K., Zhou, L.K., Van Cleemput, O., Wang, Z.J., 2000. Fate of urea- ${ }^{15} \mathrm{~N}$ in a soil-wheat system as influenced by urease inhibitor hydroquinone and nitrification inhibitor dicyandiamide. Plant Soil 220 (1-2), 261-270.

Yan, G.X., Zheng, X.H., Cui, F., Yao, Z.S., Zhou, Z.X., Deng, J., et al., 2013. Two-year simultaneous records of $\mathrm{N}_{2} \mathrm{O}$ and NO fluxes from a farmed cropland in the northern China plain with a reduced nitrogen addition rate by one-third. Agric. Ecosyst. Environ. 178, 39-50.

Yan, H.L., Xie, L.Y., Guo, L.P., Fan, J.W., Diao, T.T., Lin, M., et al., 2014. Characteristics of nitrous oxide emissions and the affecting factors from vegetable fields on the North China Plain. J. Environ. Manag. 144, 316-321.

Yang, R., Ti, C.P., Li, F.Y., Deng, M.H., Yan, X.Y., 2010. Assessment of $\mathrm{N}_{2} \mathrm{O}, \mathrm{NO}_{\mathrm{x}}$ and $\mathrm{NH}_{3}$ emissions from a typical rural catchment in Eastern China. Soil Sci. Plant Nutr. 56 (1), 86-94.

Yienger, J.J., Levy, H., 1995. Empirical-model of global soil-biogenic $\mathrm{NO}_{x}$ emissions. J. Geophys. Res. 100 (D6), 11447-11464.

Zaman, M., Blennerhassett, J.D., 2010. Effects of the different rates of urease and nitrification inhibitors on gaseous emissions of ammonia and nitrous oxide, nitrate leaching and pasture production from urine patches in an intensive grazed pasture system. Agric. Ecosyst. Environ. 136 (3-4), 236-246.

Zaman, M., Nguyen, M.L., Blennerhassett, J.D., Quin, B.F., 2008. Reducing $\mathrm{NH}_{3}, \mathrm{~N}_{2} \mathrm{O}$ and $\mathrm{NO}_{3}^{-} \mathrm{N}$ losses from a pasture soil with 
urease or nitrification inhibitors and elemental S-amended nitrogenous fertilizers. Biol. Fertil. Soils 44, 693-705.

Zhang, Y.Y., Liu, J.F., Mu, Y.J., Pei, S.W., Lun, X.X., Chai, F.H., 2011. Emissions of nitrous oxide, nitrogen oxides and ammonia from a maize field in the North China Plain. Atmos. Environ. 45 (17), 2956-2961.

Zhang, Y.Y., Liu, J.F., Mu, Y.J., Xu, Z., Pei, S.W., Lun, X.X., et al., 2012. Nitrous oxide emissions from a maize field during two consecutive growing seasons in the North China Plain. J. Environ. Sci. 24 (1), 160-168.

Zhang, Y.Y., Mu, Y.J., Fang, S.X., Liu, J.F., 2013. An improved GC-ECD method for measuring atmospheric $\mathrm{N}_{2} \mathrm{O}$. J. Environ. Sci. 25 (3), 547-553.
Zhang, Y., Mu, Y., Zhou, Y., Liu, J., Zhang, C., 2014. Nitrous oxide emissions from maize-wheat field during 4 successive years in the North China Plain. Biogeosciences 11 (7), 1717-1726.

Zheng, X.H., Mei, B.L., Wang, Y.H., Xie, B.H., Wang, Y.S., Dong, H.B., et al., 2008. Quantification of $\mathrm{N}_{2} \mathrm{O}$ fluxes from soil-plant systems may be biased by the applied gas chromatograph methodology. Plant Soil 311 (1-2), 211-234.

Zou, J.W., Huang, Y., Jiang, J.Y., Zheng, X.H., Sass, R.L., 2005. A 3-year field measurement of methane and nitrous oxide emissions from rice paddies in China: effects of water regime, crop residue, and fertilizer application. Glob. Biogeochem. Cycles 19 (2), GB2021. 